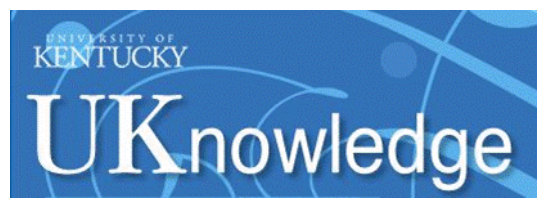

University of Kentucky

UKnowledge

\title{
Determination of Chemical Speciation of Arsenic and Selenium in High-As Coal Combustion Ash by X-Ray Photoelectron Spectroscopy: Examples from a Kentucky Stoker Ash
}

\author{
Biao Fu \\ University of Science and Technology of China, China \\ James C. Hower \\ University of Kentucky, james.hower@uky.edu \\ Shifeng Dai \\ China University of Mining and Technology, China \\ Sarah M. Mardon \\ University of Kentucky, sarah.mardon@uky.edu \\ Guijian Liu \\ University of Science and Technology of China, China \\ Follow this and additional works at: https://uknowledge.uky.edu/caer_facpub \\ Part of the Chemical Engineering Commons, and the Materials Science and Engineering Commons \\ Right click to open a feedback form in a new tab to let us know how this document benefits you.
}

\section{Repository Citation}

Fu, Biao; Hower, James C.; Dai, Shifeng; Mardon, Sarah M.; and Liu, Guijian, "Determination of Chemical Speciation of Arsenic and Selenium in High-As Coal Combustion Ash by X-Ray Photoelectron Spectroscopy: Examples from a Kentucky Stoker Ash" (2018). Center for Applied Energy Research Faculty and Staff Publications. 23.

https://uknowledge.uky.edu/caer_facpub/23

This Article is brought to you for free and open access by the Center for Applied Energy Research at UKnowledge. It has been accepted for inclusion in Center for Applied Energy Research Faculty and Staff Publications by an authorized administrator of UKnowledge. For more information, please contact UKnowledge@lsv.uky.edu. 


\section{Determination of Chemical Speciation of Arsenic and Selenium in High-As Coal Combustion Ash by X-Ray Photoelectron Spectroscopy: Examples from a Kentucky Stoker Ash}

Digital Object Identifier (DOI)

https://doi.org/10.1021/acsomega.8b02929

Notes/Citation Information

Published in ACS Omega, v. 3, issue 12, p. 17637-17645.

(C) 2018 American Chemical Society

This is an open access article published under an ACS AuthorChoice License, which permits copying and redistribution of the article or any adaptations for non-commercial purposes. 


\title{
Determination of Chemical Speciation of Arsenic and Selenium in High-As Coal Combustion Ash by X-ray Photoelectron Spectroscopy: Examples from a Kentucky Stoker Ash
}

\author{
Biao Fu, ${ }^{\dagger}$ James C. Hower, ${ }^{*}{ }^{\ddagger}$ (๑) Shifeng Dai, ${ }^{\S}$ Sarah M. Mardon," and Guijian Liu ${ }^{\dagger}$ \\ ${ }^{\dagger}$ CAS Key Laboratory of Crust-Mantle Materials and Environment, School of Earth and Space Sciences, University of Science and \\ Technology of China, Hefei, Anhui 230026, China \\ ${ }^{\ddagger}$ Center for Applied Energy Research, University of Kentucky, 2540 Research Park Drive, Lexington, Kentucky 40511, United States \\ ${ }^{\S}$ State Key Laboratory of Coal Resources and Safe Mining, China University of Mining and Technology, China, Beijing 100083, \\ China \\ "Office of Philanthropy, University of Kentucky, Lexington, Kentucky 40506, United States
}

Supporting Information

ABSTRACT: Knowledge of the chemical speciation of arsenic and selenium in coal fly ash is essential in the evaluation of the environmental behavior of fly ash disposed in a landfill in a natural environment. In this study, a series of high-As coal fly ash from stoker boilers were collected to determine the chemical forms of arsenic and selenium. The ash surface chemical characteristics and the speciation of arsenic and selenium were characterized by X-ray photoelectron spectroscopy and X-ray-induced Auger electron spectroscopy. The results indicate that the surface enrichment ratio for selenium (63.3-309.5) is higher than that of arsenic (1.2-21.2). The Wagner chemical-state plot of arsenic indicates that As is mainly present as $\mathrm{As}(\mathrm{V})$ bonded to oxygen ligands, that is, the $\left[\mathrm{AsO}_{4}\right]^{3-}$ anion; Se is found predominantly as elemental Se $(62.0-83.3 \%)$, followed by selenite $(16.7-38 \%)$. The extreme enrichment of both arsenic and selenium arsenic is controlled by iron oxides in the coal fly ash.

\section{INTRODUCTION}

Metalloid arsenic and selenium are known volatile elements of environmental concern, which can be potentially released from coal-fired power plants. ${ }^{1}$ During high-temperature combustion, volatile elements arsenic and selenium in coal may be completely vaporized and significantly condensed onto the fly ash surface. ${ }^{1,2}$ Coal combustion byproducts (fly ash) are considered to be a main potential source of trace elements for the environment. ${ }^{3,4}$ One of the concerns regarding As and Se in coal fly ash is their natural leaching into the environment when the ash is disposed in landfills or ash ponds. ${ }^{4}$ The leaching behavior of arsenic and selenium in fly ash is largely controlled by their chemical speciation. ${ }^{4-6}$ Arsenic in coal fly ash occurs mainly as pentavalent arsenate $[\mathrm{As}(\mathrm{V})]$ with minor trivalent arsenite $[\mathrm{As}(\mathrm{III})]$, which might be associated with glass, iron (oxyhydr) oxides, and calcium arsenate; ${ }^{7-10}$ these As-bearing chemical species in fly ash are stable under oxic environment but might be mobile and bioavailable under anoxic conditions. ${ }^{10}$ Compared to the inert elemental selenium $\left(\mathrm{Se}^{0}\right)$, the oxidation state of $\mathrm{Se}$ such as selenite $\left[\mathrm{SeO}_{3}{ }^{2-}\right.$, $\mathrm{Se}(\mathrm{IV})]$ and selenate $\left[\mathrm{SeO}_{4}{ }^{2-}, \mathrm{Se}(\mathrm{VI})\right]$ is labile and highly soluble. ${ }^{11}$ In general, in an oxidizing alkaline environment, selenium is much more mobile and soluble. ${ }^{6}$

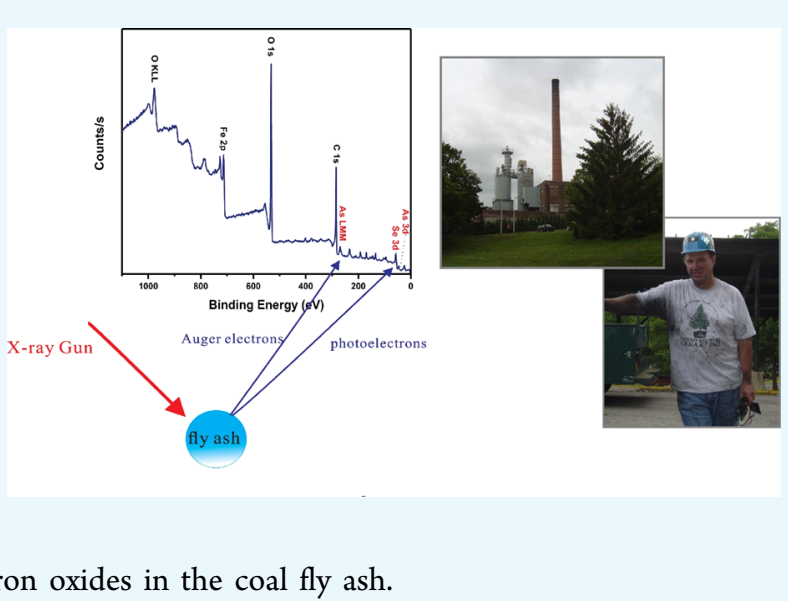

Coal fly ash is a complicated heterogeneous material, mainly consisting of glassy materials with minor mineral phases and unburned carbon. ${ }^{12}$ The chemical speciation of arsenic and selenium in the fly ash can be determined by indirect and direct methods. Direct determination of the chemical speciation of arsenic and selenium in coal fly ash is an important but difficult task because of their low concentration and heterogeneity in fly ash. Hower et al. ${ }^{13}$ used highresolution transmission electron microscopy (HRTEM) combined with energy-loss spectroscopy to demonstrate that the nanocarbon particles can host heavy metals and metalloids including $\mathrm{Hg}$, As, Se, and $\mathrm{Pb}$. Synchrotron X-ray absorption spectroscopy (XAS) is a primary technique to detect the chemical species of metal(loid)s in coal or coal fly ash., ${ }^{6,8}$ However, access to this energy spectroscopy technique is not easy, and it can be expensive. In addition to TEM and XAS, Xray photoelectron spectroscopy (XPS) is the other wellestablished nondestructive surface analysis technique for characterizing the surface chemical state of metal(loid)s in

Received: October 24, 2018

Accepted: December 5, 2018

Published: December 18, 2018 
Table 1. Major Element (Oxide wt \%), Carbon, Sulfur, As $(\mu \mathrm{g} / \mathrm{g})$, and Se ( $\mu \mathrm{g} / \mathrm{g}$ ) Data for Fly Ash Samples (Dry Basis)

\begin{tabular}{|c|c|c|c|c|c|c|c|c|c|c|c|c|c|c|c|}
\hline sample number & $\mathrm{SiO}_{2}$ & $\mathrm{TiO}_{2}$ & $\mathrm{Al}_{2} \mathrm{O}_{3}$ & $\mathrm{Fe}_{2} \mathrm{O}_{3}$ & $\mathrm{MgO}$ & $\mathrm{CaO}$ & $\mathrm{MnO}$ & $\mathrm{Na}_{2} \mathrm{O}$ & $\mathrm{K}_{2} \mathrm{O}$ & $\mathrm{P}_{2} \mathrm{O}_{5}$ & LOI (\%) & C (\%) & S (\%) & As & $\mathrm{Se}$ \\
\hline 93259 whole ash & 39.50 & 1.31 & 20.71 & 31.52 & 0.56 & 1.35 & 0.17 & 0.51 & 1.32 & 3.04 & 25.31 & 15.19 & 1.61 & 4876 & 256 \\
\hline 93260 whole ash & 39.66 & 1.33 & 20.26 & 29.87 & 0.54 & 1.32 & 0.19 & 0.64 & 1.36 & 4.85 & 25.34 & 17.61 & 1.50 & 8450 & 230 \\
\hline 93261 whole ash & 52.25 & 2.26 & 26.13 & 11.81 & 0.67 & 2.03 & 0.04 & 1.03 & 2.18 & 1.59 & 38.62 & 25.42 & 2.13 & 1378 & 200 \\
\hline $93259+60$ mesh & 3.24 & 0.08 & 2.12 & 89.12 & 0.13 & 0.11 & 0.54 & 0.25 & 0.21 & 4.17 & 11.22 & 4.07 & 1.18 & 8022 & 222 \\
\hline $9325960 \times 100$ mesh & 15.72 & 0.37 & 10.43 & 65.52 & 0.29 & 0.28 & 0.32 & 0.25 & 0.57 & 6.25 & 22.98 & 14.25 & 1.09 & 9379 & 305 \\
\hline $93259100 \times 200$ mesh & 31.30 & 0.90 & 19.23 & 41.84 & 0.47 & 0.74 & 0.16 & 0.29 & 0.92 & 4.16 & 25.65 & 18.57 & 0.88 & 5768 & 321 \\
\hline $93259200 \times 325$ mesh & 44.84 & 1.66 & 24.39 & 23.25 & 0.56 & 1.49 & 0.07 & 0.27 & 1.28 & 2.20 & 20.45 & 15.07 & 0.64 & 2856 & 288 \\
\hline $93259325 \times 500$ mesh & 48.91 & 1.99 & 25.48 & 18.02 & 0.59 & 1.86 & 0.05 & 0.27 & 1.40 & 1.43 & 17.25 & 12.87 & 0.51 & 1663 & 225 \\
\hline 93259500 mesh & 51.23 & 2.29 & 24.88 & 15.99 & 0.50 & 1.12 & 0.03 & 0.22 & 1.65 & 2.08 & 33.40 & 23.16 & 0.85 & 2033 & 260 \\
\hline
\end{tabular}

the fly ash. ${ }^{7,14-16}$ The presence of peak at $48.5 \mathrm{eV}$ could be assigned to As $3 \mathrm{~d}$ for arsenic oxides in coal fly ash. ${ }^{15}$ Goodarzi $^{7}$ indicated that $\mathrm{As}^{5+}$ is the dominant form of arsenic in several Canadian coal fly ashes, and As was found to be greatly enriched on the surface of fly ash. Yan et al. ${ }^{17}$ assigned two peaks of Se $3 \mathrm{~d}$ to elemental $\mathrm{Se}(56 \mathrm{eV})$ and $\mathrm{SeO}_{2}(60 \mathrm{eV})$ in the cooled aerosol particles generated from lab-scale coal/coke combustion experiments. However, XPS may not give accurate information on the chemical state of one element because the binding energy values for the specific chemical state of some elements vary in a relatively wide range. For example, the binding energies of $\mathrm{As}(\mathrm{V})-\mathrm{O}$ bonds are 44.9, 45.6, and 46.8 $\mathrm{eV}$ for $\mathrm{Na}_{2} \mathrm{HAsO}_{4} \cdot \mathrm{H}_{2} \mathrm{O}, \mathrm{FeAsO}_{4} \cdot 2 \mathrm{H}_{2} \mathrm{O}$, and $\mathrm{As}_{2} \mathrm{O}_{5}$, respectively. ${ }^{18}$ More accurate determination of the chemical state of elements can be obtained by a two-dimensional Wagner chemical-state plot. $^{18-20}$ The Wagner plot, which combines the data of core-level binding energy with the kinetic energy of the Auger transition, has been successfully used to identify the chemical state of elements in heterogeneous natural samples and to avoid ambiguous results. ${ }^{18,20,21}$ Therefore, it might be a practical method to clearly identify As and Se species in coal fly ash.

The chemical speciation of trace elements in coal fly ash is dependent upon feed-coal properties, combustion conditions, boiler types, air pollution control devices, etc. ${ }^{2,7}$ Much of the detailed information on the chemical speciation of As and Se in coal fly ash has focused on pulverized-coal combustors ${ }^{7,8,13}$ or fluidized-bed boilers. ${ }^{5,7}$ Coal stoker boilers are also an important boiler type, which are widely used in a variety of applications. $^{22}$ Nevertheless, direct determination of the surface chemistry and chemical speciation of metal(loid)s in stoker ash is lacking. In this study, the surface chemical characteristics and speciation of As and Se in the stoker ash are studied using XPS and X-ray-induced Auger electron spectroscopy (XAES). As reported by Mardon et al., ${ }^{22}$ the concentration of As in the studied ash samples exceeded $1000 \mu \mathrm{g} / \mathrm{g}$. On the basis of the bulk analysis, Mardon et al. ${ }^{22}$ also suggested that arsenic in the stoker ash might be present as "a condensate on the surface of the $\mathrm{Al}-\mathrm{Si}$ ash particles" or as "a component in a fine carbon fraction". However, this speculation concerning the chemical speciation of arsenic in the fly ash lacked direct evidence. The extremely high-As stoker ash provides a good opportunity to study the chemical speciation of arsenic and selenium in fly ash. These samples in this study are designed to obtain more precise information on the chemical speciation of As and Se in the stoker fly ash using XPS and XAES. To the best of author's knowledge, the research may be the first time the XPS-XAES technique has been used to characterize the chemical speciation of As and Se in coal fly ash. The results of this study also can provide not only important information on the modes of As and Se occurrences in fly ash but also a more practical option for researchers to identify As and Se species in other complex environmental samples compared to synchrotron-based analysis.

\section{MATERIALS AND METHODS}

2.1. Sample Collection. Three stoker fly ashes, 93259 (first row of the hoppers), 93260, and 93261, were collected in July 2006 from three successive baghouse hoppers of the Eastern Kentucky University (EKU) heating boilers. The whole ash 93259 was screened at 60, 100, 200, 325, and 500 mesh, respectively.

2.2. Chemical Analysis. Bulk chemical analysis reported by Mardon et al. ${ }^{22}$ was supplemented with a more detailed examination of the samples used in this study. In detail, the concentration of major element oxides and trace elements was determined for the screened ash samples in this study. Especially, supplementary determination of rare earth elements and selenium in all ash samples was also carried out in this study (Table S1). Mercury was determined using a Milestone DMA-80 analyzer (with a 0.005 ng detection limit) based on the methods of Dai et al. ${ }^{23}$ Concentrations of other trace elements in the fly ash were determined by quadrupole-based inductively coupled plasma mass spectrometry (Thermo Fisher, $\mathrm{X}$ series II ICP-MS). In order to reduce the spectral interferences of the Ar-based polyatomic ions ${ }^{40} \mathrm{Ar}{ }^{35} \mathrm{Cl}$ and ${ }^{40} \mathrm{Ar}{ }^{38} \mathrm{Ar}$ to ${ }^{75} \mathrm{As}$ and ${ }^{78} \mathrm{Se}$, respectively, the concentrations of As and $\mathrm{Se}$ in samples were determined by ICP-MS using collision/reaction cell technology, following the procedures outlined by $\mathrm{Li}$ et $\mathrm{al}^{24}$ Boron concentrations were also determined by ICP-MS after digestion of the solid sample (50 mg) using a mixture of $\mathrm{H}_{3} \mathrm{PO} 4, \mathrm{HNO}_{3}$, and $\mathrm{HF}$; a $2 \%$ ammonia solution was injected into the spray chamber of the ICP-MS facility to eliminate the memory effect of boron. ${ }^{25}$ Prior to ICP-MS analysis, all samples were digested using a closed vessel microwave digestion system (Milestone UltraClave).

Analysis of surface chemistry for the ash samples was performed on an XPS spectrometer (ESCALAB $250 \mathrm{Xi}$, Thermo VG Scientific) using a monochromatic Al K $\alpha$ (1486.6 eV, $150 \mathrm{~W}$ ) X-ray source. Survey scan analyses were carried out with a spot size of $500 \mu \mathrm{m}^{2}$ area and a pass energy of 30 $\mathrm{eV}$. High-resolution scan analyses of the ash samples were performed to obtain the spectra of C 1s, O 1s, S 2p, Fe 2p, Ca $2 \mathrm{p}$, As $2 \mathrm{p}$, As $3 \mathrm{~d}$, and Se $3 \mathrm{~d}$. The energy step size for the narrow scan analysis was $0.05 \mathrm{eV}$. The final high-resolution scan spectrum was obtained with at least three times of scan for each element. To compensate for the charging effects, all the spectra have been corrected to the C 1s spectra set to 284.8 

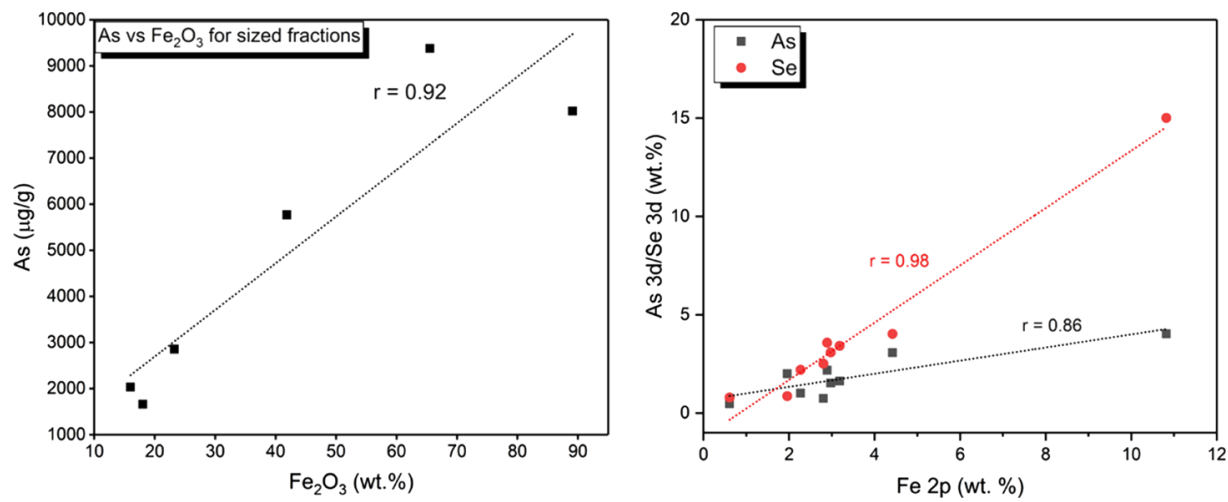

Figure 1. Correlations between As and iron oxides (left) in the whole coal fly ash (bulk analysis) and correlations between the surface concentration of As/Se and the Fe content by XPS surface analysis.

$\mathrm{eV}^{26}$ Photoelectron lines after nonlinear background subtraction (Shirley) were fitted with Gaussian/Lorentzian functions using CasaXPS (version 2.3.13) software. In addition to the photoelectronic lines of As $3 \mathrm{~d}$ and Se 3d, the X-rayinduced Auger lines of arsenic (As LMM) and selenium (Se LMM) were also examined. These data can be used to obtain the Auger parameter and the chemical-state plot to clearly distinguish the chemical states of As and Se in the fly ash samples. $^{18,19}$

\section{RESULTS AND DISCUSSION}

3.1. Chemical Compositions of Fly Ash. Results of bulk analysis of fly ash are listed in Table 1 . The long version of the data table, which includes all the element concentration results, can be found in the Supporting Information (Table S1). In this study, $\mathrm{Si}, \mathrm{Al}, \mathrm{C}$, and $\mathrm{Fe}$ are the dominant elements for the three raw fly ash samples, which are generally consistent with the mineralogical compositions of quartz, mullite, and hematite. ${ }^{27}$ The concentration of arsenic is significantly higher than the reported values (typically in the range of $1-1000 \mu \mathrm{g} / \mathrm{g}$ ) in most other coal fly ashes. ${ }^{5,10,28}$ Selenium is also enriched in the raw fly ash (Table 1). Further, as shown in Figure 1, there is a strong linear relationship between $\mathrm{Fe}_{2} \mathrm{O}_{3}$ and As, suggesting that the deposition of arsenic onto the fly ash surface may be associated with iron oxides.

Figure 2 is a typical survey spectrum of fly ash (9325960 mesh). The major chemical compositions in the fly ash sample determined by XPS are $\mathrm{C}, \mathrm{O}, \mathrm{Si}, \mathrm{Al}, \mathrm{Fe}, \mathrm{P}$, and $\mathrm{S}$, corresponding to the binding energies of $285,532,104,74$, and $712 \mathrm{eV}$, respectively (Table 2; Figure 1). Minor elements (less than 1\%, sometimes detected at the noise levels) specifically $\mathrm{Ti}, \mathrm{Na}, \mathrm{Mg}$, and $\mathrm{Ca}$ are also identified. Main peaks of As 3d and Se 3d can be clearly observed at ca. 46 and $57 \mathrm{eV}$, respectively, in the high-resolution spectra (Figures 3 and 6). Especially, in comparison with the element contents in the whole coal fly ash (bulk analysis), the mass percentage of As and Se in most ash surfaces is larger than 1 wt \% (Table 2), suggesting a significant surface enrichment. In addition, the correlation coefficient values between As versus $\mathrm{Fe}$ and $\mathrm{Se}$ versus $\mathrm{Fe}$ in the fly ash surface are 0.86 and 0.98 , respectively (Figure 2), indicating that Fe may play an important role in the As and Se surface retention.

3.2. Comparison between XPS Surface Analysis and Bulk Analysis. In this study, the element contents in the fly ash surface determined by XPS are all normalized to Al. The method has been used in previous studies ${ }^{14,15}$ because, during

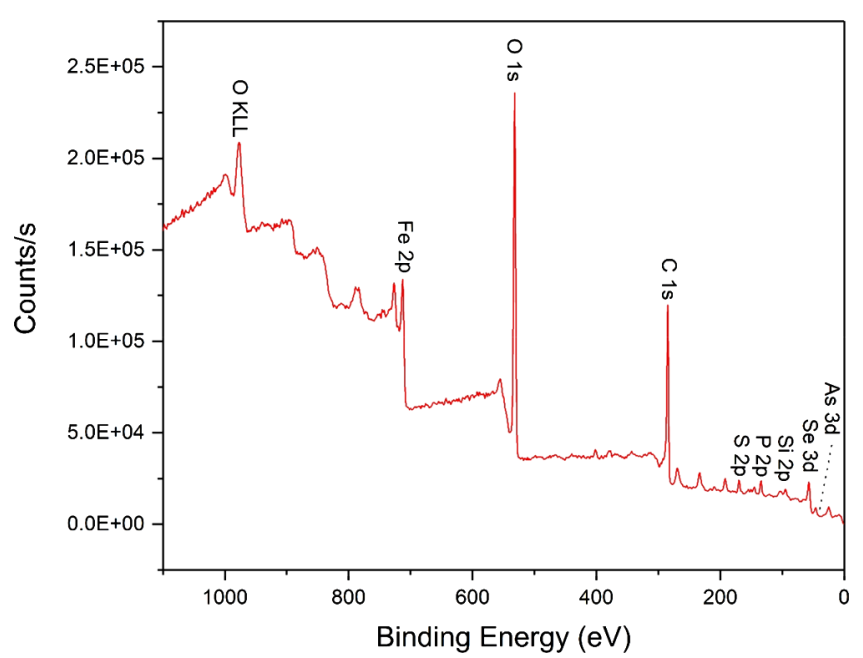

Figure 2. Survey spectrum of fly ash (9325960 mesh).

coal combustion, Al was a conservative element, therefore minimizing the variability in ash compositions and reflecting the differential enrichment behavior of elements. ${ }^{14}$ To assess the surface enrichment of elements in fly ash, the enrichment ratio (ER) is calculated based on formula 1

$$
\mathrm{ER}=\frac{\mathrm{MS}_{\mathrm{i}} / \mathrm{Al}_{\mathrm{s}}}{\mathrm{MB}_{\mathrm{i}} / \mathrm{Al}_{\mathrm{b}}}
$$

where $M S_{i}$ and $M B_{i}$ represent the mass concentration of each element in the ash surface (XPS analysis) and in the whole coal fly ash (bulk analysis), respectively. As shown in Table 2, the ER value of $S i$ varies in the range of $0.85-1.67$, suggesting that $\mathrm{Si}$ generally is evenly distributed throughout the whole ash. $^{14-16}$ For $\mathrm{Fe}$, the $\mathrm{ER}$ value $(<1)$ indicates that $\mathrm{Fe}$ is present much more in the interior than the outer surface. ${ }^{29}$ However, although the ash surface is not enriched in $\mathrm{Fe}, \mathrm{Fe}$ is a still major component on the surface of some of the fly ash particles, as discussed above. For C, S, P, As, and Se, the ER value is larger than 1 , which is an indication of surface enrichment of these elements onto the fly ash surface. On the basis of the high ER values for Se (63-309), it can be inferred that extensive absorption/condensation of gaseous Se species onto the fly ash surface may occur in the post-combustion process. Note that although the concentrations of Se (200$321 \mu \mathrm{g} / \mathrm{g}$ ) in the whole ash are much lower than that of As $(1378-9379 \mu \mathrm{g} / \mathrm{g})$, Se contents on the ash surface are higher 
Table 2. XPS Surface Chemical Composition of Coal Fly Ash (wt \%) and the Surface ER

\begin{tabular}{|c|c|c|c|c|c|c|c|c|c|c|c|c|c|c|c|c|}
\hline & \multicolumn{15}{|c|}{ surface analysis (wt \%) } & \multirow{2}{*}{$\begin{array}{l}\mathrm{ER} \\
\mathrm{Fe}\end{array}$} \\
\hline & Si $2 p$ & $\mathrm{Al} \mathrm{2p}$ & $\mathrm{Fe} 2 \mathrm{p}$ & P 2p & As $3 d$ & Se 3d & $\mathrm{C} 1 \mathrm{~s}$ & S $2 p$ & $\mathrm{Si}$ & $\mathrm{Fe}$ & $\mathrm{P}$ & As & $\mathrm{Se}$ & $\mathrm{C}$ & S & \\
\hline 93259 whole ash & 15.05 & 7.93 & 2.27 & 1.68 & 1.01 & 2.20 & 35.88 & 4.2 & 1.1 & 0.1 & 1.8 & 1.7 & 136.6 & 3.3 & 3.6 & 22.05 \\
\hline 93260 whole ash & 11.44 & 4.42 & 1.96 & 3.08 & 1.99 & 0.86 & 41.50 & 4.8 & 1.5 & 0.2 & 3.5 & 9.9 & 81.2 & 5.7 & 7.8 & 20.89 \\
\hline 93261 whole ash & 11.44 & 5.67 & 0.61 & 1.08 & 0.48 & 0.79 & 45.82 & 5.8 & 1.1 & 0.2 & 3.8 & 1.2 & 63.3 & 4.4 & 6.6 & 8.26 \\
\hline $93259+60$ mesh & 2.59 & 2.26 & 10.82 & 5.49 & 4.02 & 15.01 & 26.33 & 3.8 & 0.8 & 0.1 & 1.5 & 3.5 & 231.3 & 3.2 & 1.6 & 62.33 \\
\hline $9325960 \times 100$ mesh & 7.59 & 4.72 & 4.42 & 4.03 & 3.07 & 4.03 & 44.21 & 2.0 & 1.2 & 0.1 & 1.7 & 12.5 & 163.5 & 3.6 & 2.1 & 45.83 \\
\hline $93259100 \times 200$ mesh & 15.09 & 6.30 & 2.89 & 2.63 & 2.18 & 3.58 & 35.86 & 1.8 & 1.7 & 0.1 & 2.3 & 21.2 & 256.7 & 3.1 & 3.3 & 32.52 \\
\hline $93259200 \times 325$ mesh & 18.29 & 7.24 & 3.18 & 1.94 & 1.63 & 3.41 & 31.87 & 2.3 & 1.6 & 0.3 & 3.6 & 14.3 & 234.4 & 3.8 & 6.5 & 16.26 \\
\hline $93259325 \times 500$ mesh & 22.32 & 8.57 & 2.98 & 2.04 & 1.53 & 3.09 & 23.76 & 1.7 & 1.5 & 0.4 & 5.1 & 2.8 & 211.5 & 2.9 & 5.3 & 12.61 \\
\hline 93259500 mesh & 14.56 & 5.36 & 2.80 & 1.92 & 0.74 & 2.51 & 42.87 & 2.3 & 1.5 & 0.6 & 5.2 & 13.2 & 309.5 & 4.5 & 6.7 & 11.18 \\
\hline
\end{tabular}
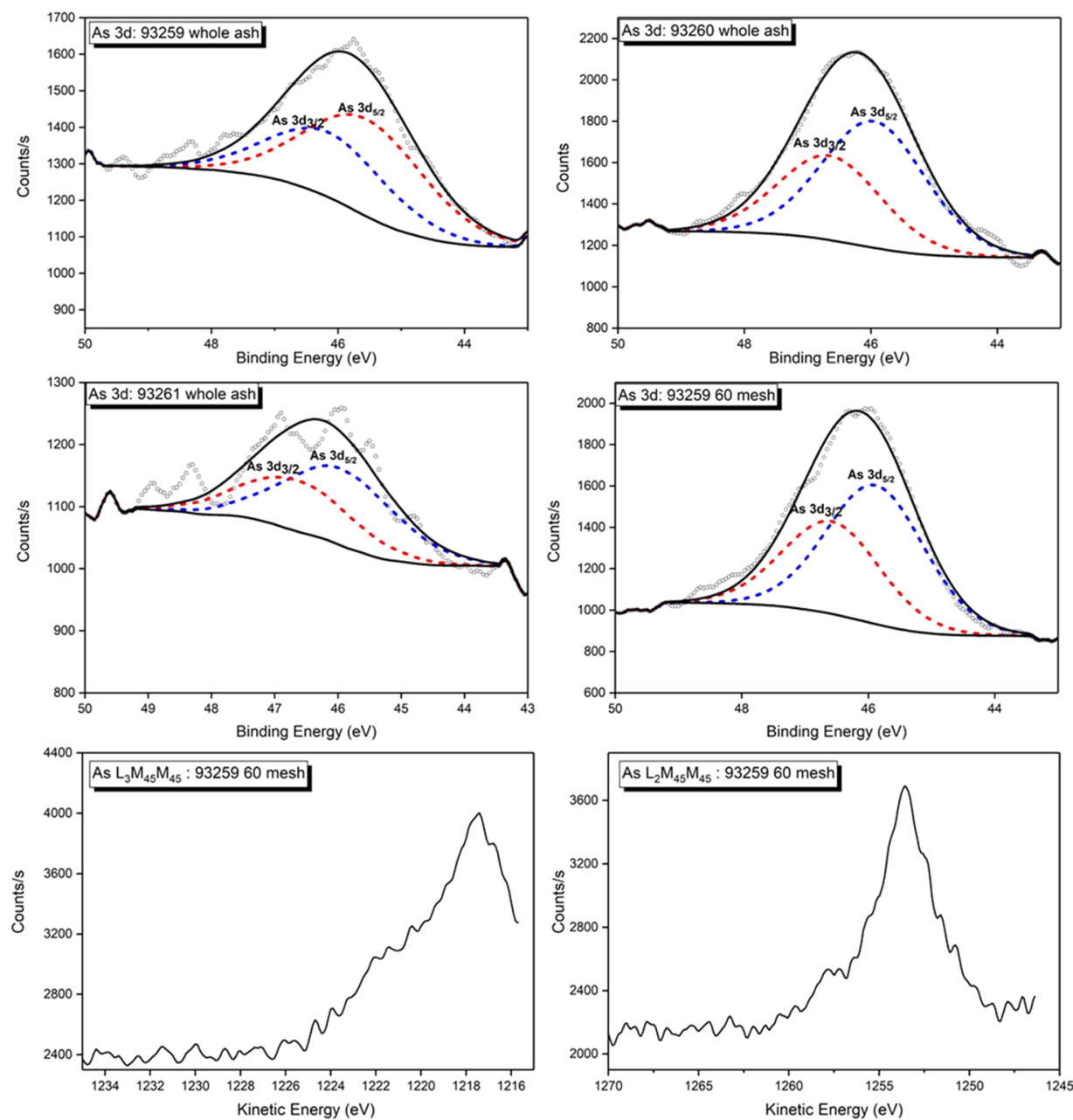

Figure 3. As 3d signal and As LMM lines for selected fly ash samples detected by both XPS and XAES techniques. Black solid lines and dasheddotted lines refer to best-fit and experimental curves, respectively. The peak assignment obtained by deconvolution is shown as red dashed lines and blue dashed lines. The Shirley background is added to each As 3d spectrum.

than that of As (with the exception of the sample 93261) because of the more intense surface enrichment of Se in fly ash.

3.3. Chemical State of As. In this study, all the fly ash samples are subjected to XPS analysis to obtain the As 3d spectra and four of the samples are determined by both XPS and XAES techniques. Table 3 summarizes the results of peak position for As $3 \mathrm{~d}$, As $2 \mathrm{p}_{3 / 2}$, As $\mathrm{L}_{2} \mathrm{M}_{45} \mathrm{M}_{45}$, As $\mathrm{L}_{3} \mathrm{M}_{45} \mathrm{M}_{45}$ lines, and Auger parameter. It should be noted that photoelectron lines of $S$ 2s may overlap with As $\mathrm{L}_{2} \mathrm{M}_{45} \mathrm{M}_{45}$ (Figure 3). To overcome this problem, Auger lines of As $\mathrm{L}_{3} \mathrm{M}_{45} \mathrm{M}_{45}$ are chosen to obtain the Auger parameters. ${ }^{21}$ The selected XPS and XAES spectra of arsenic in coal fly ash are shown in Figure 3. The high-resolution spectra of As $3 \mathrm{~d}$ for all the ash samples, after Shirley-background subtraction, are fitted with $A s 3 \mathrm{~d}_{5 / 2}$ and As $3 \mathrm{~d}_{3 / 2}$ doublet with a binding energy difference of $0.7 \mathrm{eV}$ and an area ratio of $3: 2$.

In general, the As $3 \mathrm{~d}$ spectra show minor variations among all the samples. The binding energy values of $A s 3 d_{5 / 2}$ are in the range of $45.7-46.1 \mathrm{eV}$, suggesting that arsenic might be present as $\mathrm{As}(\mathrm{V})$. The As $\mathrm{L}_{3} \mathrm{M}_{45} \mathrm{M}_{45}$ lines in the $\mathrm{X}$-ray absorption near-edge structure (XANES) spectra are found between 1216 and $1218 \mathrm{eV}$. Consequently, the modified Auger 
Table 3. XPS and XAES Results of Peak Position for As 2p, As 3d, As 2p $p_{3 / 2}$, As $L_{2} M_{45} M_{45}$, As $L_{3} M_{45} M_{45}$ Lines, and Auger Parameter; Unit: eV

\begin{tabular}{|c|c|c|c|c|c|c|}
\hline sample & $2 p$ & $3 d$ & $3 d_{5 / 2}$ & $\mathrm{~L}_{2} \mathrm{M}_{45} \mathrm{M}_{45}$ & $\mathrm{~L}_{3} \mathrm{M}_{45} \mathrm{M}_{45}$ & $\alpha+h \nu$ \\
\hline 9325960 mesh & 1327 & 45.9 & 45.9 & 1254 & 1218 & 1263.35 \\
\hline $9325960 \times 100 \mathrm{mesh}$ & 1328 & 46.4 & 45.9 & 1253 & 1217 & 1263.10 \\
\hline $93259100 \times 200$ mesh & 1328 & 45.8 & 45.8 & 1253 & 1218 & 1263.28 \\
\hline 93261 whole ash & 1328 & 46.9 & 46.1 & 1253 & 1217 & 1263.44 \\
\hline 93260 whole ash & & 46.9 & 46.1 & & & \\
\hline 93259 whole ash & & 45.8 & 45.6 & & & \\
\hline $93259200 \times 325$ mesh & & 46.05 & 45.8 & & & \\
\hline $93259325 \times 500$ mesh & & 46.1 & 45.7 & & & \\
\hline 93259500 mesh & & 45.9 & 45.7 & & & \\
\hline 93261 whole ash & & 45.9 & 45.8 & & & \\
\hline
\end{tabular}

parameter $\alpha^{\prime}$, defined based on the original Auger parameter $(\alpha)$ as Wagner suggested, ${ }^{19}$ can be obtained based on formula 2

$$
\alpha^{\prime}=\alpha+h \nu=E_{\mathrm{K}}+E_{\mathrm{B}}
$$

where $E_{\mathrm{K}}$ and $E_{\mathrm{B}}$ represent the kinetic energy of the sharpest Auger line and binding energy of the most intense photoelectron line. The Auger parameter $\alpha^{\prime}$ is independent of charging effect and quite useful to identify the chemical state in insulator samples. ${ }^{18,19,30}$ As shown in Table 3, arsenic in the fly ash samples has an Auger parameter of $1263.3 \pm 0.2 \mathrm{eV}$. The calculated Auger parameter is plotted on the Wagner chemicalstate plot as a series of diagonal lines.

The Wagner chemical-state plot for arsenic as well as several arsenic-bearing compounds from NIST XPS database ${ }^{39}$ and published data $^{18,21,30}$ is depicted in Figure 4. In the chemical-

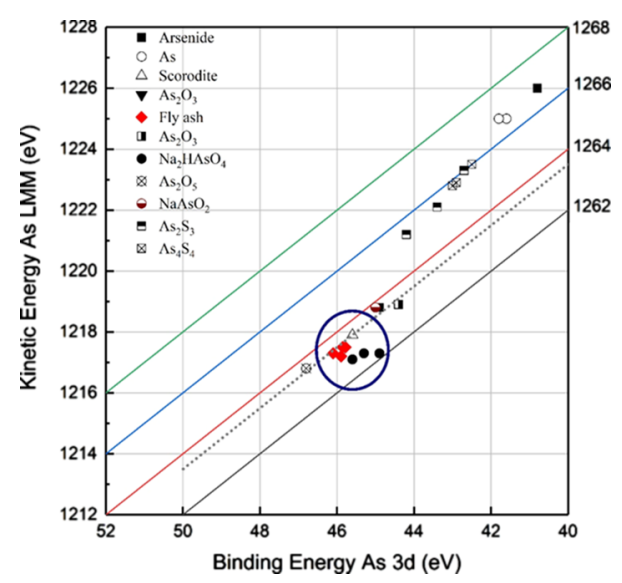

Figure 4. Wagner chemical-state plot for arsenic in coal fly ash and in several arsenic-bearing compounds from NIST XPS database and published data.

state plot, it is observed that all the data points of the fly ash samples fall on a diagonal line with the Auger parameter of $1263.5 \mathrm{eV}$. These points of analyzed fly ash are close to scorodite $\left(\mathrm{FeAsO}_{4} \cdot 2 \mathrm{H}_{2} \mathrm{O}\right)$ and $\mathrm{Na}_{2} \mathrm{HAsO}_{4}$ (points in the blue circle). On the basis of the arsenic chemical-state plot, other chemical states of arsenic, including As(III) oxides and $\mathrm{AsO}_{2}{ }^{-1}$, could be ruled out. This is a little different from the published data about the chemical forms of As in the coal fly ash. According to synchrotron-based XAS studies, Huggins et al. ${ }^{8}$ indicated that there was a minor fraction $(10-15 \%)$ of arsenic present as As(III) in 10 pulverized coal fly ash samples; Deonarine et al. ${ }^{10}$ reported that $3-8 \%$ of total As occur as
As(III) in two fly ash samples. In this study, arsenic in the stoker fly ash can probably be assigned to oxo-anion arsenate and might be associated with $\mathrm{Fe}$ oxides/hydroxides occurring as $\mathrm{Fe}(\mathrm{III})-\mathrm{AsO}_{4}$. As can be seen from Figure 5, $\mathrm{Fe} 2 \mathrm{p}$ in the fly ash photoelectron spectroscopy exhibits a typical doublet because of spin-orbit coupling interactions. The peak of $\mathrm{Fe}$ $2 \mathrm{p}_{3 / 2}$, situated at $711.8 \mathrm{eV}$ along with two satellites at the higher binding energy side of $\mathrm{Fe} 2 \mathrm{p}_{3 / 2}$ and $\mathrm{Fe} 2 \mathrm{p}_{1 / 2}$, is a typical spectrum of $\mathrm{Fe}$ (III) oxides and hydroxides. ${ }^{20,26}$ The presence of metal (mainly Fe) oxides/hydroxides is also supported by the high-resolution scan spectra of $\mathrm{O} 1 \mathrm{~s}$ (Figure 5). The $\mathrm{O} 1 \mathrm{~s}$ spectrum displays complex envelopes caused by different surface oxides species such as sulfates, phosphates, organics, and metal(loid)s oxides. A shoulder peak appearing at ca. 530 $\mathrm{eV}$ in the spectrum of fly ash 9325060 mesh is much more obvious (Figure 5) than that in the other ash samples. The shoulder peak for the 9325060 -mesh fly ash is a consequence of the high iron oxides content in the ash surface (Table 2). Therefore, on the basis of the XPS and XAES analysis and the strong correlations between arsenic and iron (Figure 2), arsenic in the studied stoker fly ash occurs as $\mathrm{As}(\mathrm{V})$ bonded to oxygen ligands, that is, the $\left[\mathrm{AsO}_{4}\right]^{3-}$ anion, and probably absorbed by iron oxides/hydroxides or incorporation into the Fe-bearing phases. It has been reported that $\mathrm{Fe}$ had strong correlations with As, forming As-/Fe-bearing compounds as independent minerals or As(V) sorbed to Fe(III) oxides/ hydroxides in complex natural samples (mining wastes, stream sediments, and fly ash)..$^{10,20,31}$ The chemical speciation of arsenic in this study generally agrees with fly ash samples from the Kingston fossil plant (Tennessee) that $95-100 \%$ of total As in the fly ash occurred as $\mathrm{As}(\mathrm{V})$ associated with iron (hydr)oxides and aluminosilicate glass. ${ }^{32}$ Tian et al. ${ }^{33}$ also demonstrated that arsenic occurred as $\mathrm{As}(\mathrm{V})$ in three different coal fly ash samples using XANES technology. Under a fully oxidized chemical environment, arsenate bonds strongly to iron oxide minerals as an inner-sphere complex as a bidentate, binuclear surface complex. ${ }^{34}$ In addition, the formation of calcium arsenate in the fly ash could be excluded because of the very low contents of calcium in the ash surface. ${ }^{2,5,7}$

3.4. Chemical State of Se. Selenium is one of the most volatile elements during coal combustion. ${ }^{17}$ Previous studies reported that $\mathrm{Se}$ in coal fly ash can be present as several chemical forms including elemental $\mathrm{Se}\left(\mathrm{Se}^{0}\right)$, selenite $\left[\mathrm{SeO}_{3}{ }^{2-}\right.$, $\mathrm{Se}(\mathrm{IV})]$, selenate $\left[\mathrm{SeO}_{4}{ }^{2-}, \mathrm{Se}(\mathrm{VI})\right]$, and $\mathrm{SeO}_{2}{ }^{6,8,17} \mathrm{As}$ discussed in Section 3.2, the maximum concentration of Se in the surface of fly ash is 309 times higher than the Se content in the whole ash. Therefore, the Se $3 \mathrm{~d}$ signal is strong enough to be detected in spite of the Se concentration in the whole ash 

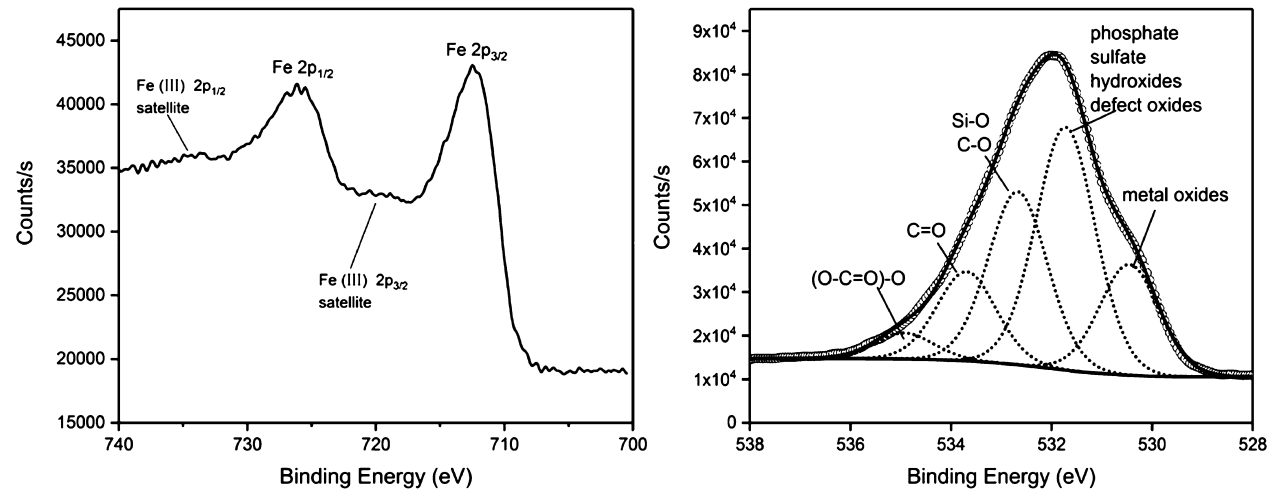

Figure 5. XPS data of Fe 2p and O 1s high-resolution spectra for the 93259 60-mesh fly ash sample.
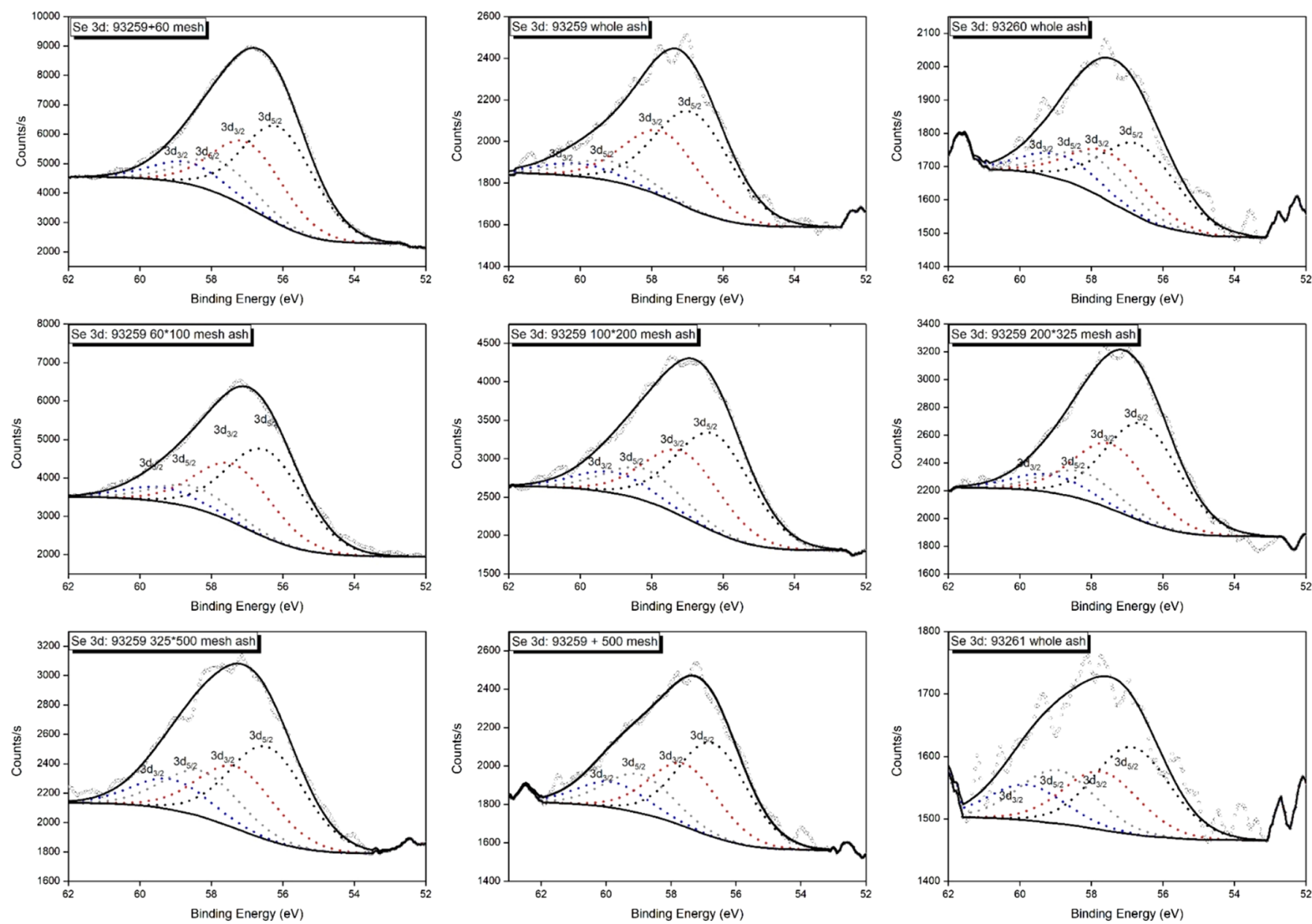

Figure 6. Se 3d high-resolution spectra for all the fly ash samples detected by XPS. Black solid lines and dashed-dotted lines refer to best-fit and experimental curves, respectively. The peak assignment obtained by deconvolution is shown as dashed lines in different colors. The Shirley background is added to each Se 3d spectrum. fwhm remains consistent during the fitting process $(2.3-2.5 \mathrm{eV})$.

being below the limit of detection of XPS (0.1 wt \%, $1000 \mu \mathrm{g} /$ g). Detailed XPS patterns of Se 3d for all fly ash samples are shown in Figure 6. The Auger lines of $\mathrm{Se}_{3} \mathrm{M}_{45} \mathrm{M}_{45}$, which are detected at the noise level, are not considered in this study. It is established that elementary $\mathrm{Se}$, selenite, selenate, and $\mathrm{SeO}_{2}$ have peaks of $S e 3 d_{5 / 2}$ at $55.4 \pm 0.7,59.1,59.4 \pm 0.6$, and 61.6 $\mathrm{eV}$, respectively. ${ }^{39}$

As described in Figure 6, the Se 3d peak for fly ash samples has a main asymmetric peak at $57 \pm 0.7 \mathrm{eV}$ with a broad binding energy range extending from 62 to $54 \mathrm{eV}$, indicating that more than one chemical state of Se occurred in the fly ash. $^{37}$ The Shirley-subtracted high-resolution spectra of Se 3d are fitted with the Se $3 \mathrm{~d}_{5 / 2}-3 \mathrm{~d}_{3 / 2}$ separation of $0.86 \mathrm{eV}$ and full width at half-maximum (fwhm) of $2.3-2.5 \mathrm{eV}$. Two chemical states of Se could be observed in the Se 3d spectra (Table 4). The first split doublet is assigned to elemental $\mathrm{Se}^{0}$ with a binding energy of Se $3 d_{5 / 2}$ at $56.5 \pm 0.2 \mathrm{eV}$; the second peak corresponds to selenite $\left(\mathrm{SeO}_{3}{ }^{2-}, \mathrm{Se}(\mathrm{IV})\right)$ with a binding energy of $58.5 \pm 0.4 \mathrm{eV}$. All the fitting results are listed in Table 4. The Se distribution in the fly ash samples is dominated by elemental Se (62.0-83.3\%), followed by selenite $(16.7-38 \%)$. $\mathrm{Se}(\mathrm{VI})$ selenate or $\mathrm{SeO}_{2}$ is not the major form 
Table 4. Fitting Results of the High-Resolution Scan Spectra of Se 3d for All the Fly Ash Samples

\begin{tabular}{lccccc} 
& \multicolumn{2}{c}{$\operatorname{Se}(0)$} & & \multicolumn{2}{c}{$\operatorname{Se}(\mathrm{IV})$} \\
\cline { 2 - 3 } \cline { 6 - 6 } \multicolumn{1}{c}{ sample } & $\begin{array}{c}\text { position } \\
(\mathrm{eV})\end{array}$ & $\begin{array}{c}\text { conc } \\
(\%)\end{array}$ & & $\begin{array}{c}\text { position } \\
(\mathrm{eV})\end{array}$ & $\begin{array}{c}\text { conc } \\
(\%)\end{array}$ \\
$\mathbf{9 3 2 5 9}$ whole ash & 56.8 & 83.3 & & 59.2 & 16.7 \\
$\mathbf{9 3 2 6 0}$ whole ash & 56.6 & 66.6 & & 58.0 & 33.5 \\
$\mathbf{9 3 2 6 1}$ whole ash & 56.9 & 62.0 & & 59.0 & 38.0 \\
$93259+60$ mesh & 56.1 & 76.8 & & 57.9 & 23.2 \\
$9325960 \times 100$ mesh & 56.5 & 80.3 & & 58.5 & 19.8 \\
$93259100 \times 200$ mesh & 56.3 & 75.6 & & 58.2 & 24.4 \\
$93259200 \times 325$ mesh & 56.6 & 78.3 & & 58.3 & 21.7 \\
$93259325 \times 500$ mesh & 56.4 & 67.1 & & 58.3 & 32.9 \\
93259500 mesh & 56.7 & 70.8 & & 59.0 & 29.2 \\
\hline
\end{tabular}

because the oxidation state of hexavalent $\mathrm{Se} 3 \mathrm{~d}_{5 / 2}$ corresponds to a higher binding energy than that of Se(IV). Therefore, the residual error for the fitting process is lowest when the Se 3d peak is fitted into elemental $\mathrm{Se}^{0}$ and selenite. The result is generally in agreement with Liu et al. ${ }^{6}$ that elemental Se is the dominant form with minor Se oxy-anions. In an earlier HRTEM study of the fly ash samples (93261 whole fly ash), Silva et al. ${ }^{27}$ observed that Se mainly occurred in the elemental form encapsulated by the carbonaceous matter. However, studies of other fly ash sources indicated that $\mathrm{Se}(\mathrm{IV})$ was the predominant phase. ${ }^{8,9,32,33}$ The variations between the chemical forms of Se in different fly ash samples might be associated with the different boiler types (stoker boiler vs pulverized-coal combustor), ash components, and the air pollution control devices.

3.5. Possible Enrichment Mechanisms for High-As/Se Fly Ash. The feed coal used in the EKU steam plant is low-S $(0.8 \%)$, high volatile A bituminous coal; trace elements, such as As $(133 \mu \mathrm{g} / \mathrm{g})$, are enriched in the feed coal, whereas Se $(1.25 \mu \mathrm{g} / \mathrm{g})$ is not concentrated. ${ }^{22}$ The extremely high concentration of arsenic and the great surface enrichment of Se in the fabric filter fly ash may, therefore, not be anticipated. However, as noted above, the chemical composition of fly ash is not solely determined by the feed coal chemistry. Combustion conditions, post-combustion process, and the air pollution control devices are also important factors affecting the element's partitioning behavior. ${ }^{1}$ It is known that the concentration of As and Se is closely associated with particle size distribution; both As and Se are found to be concentrated on the fine-grain ash particles. ${ }^{2,5,35}$ As shown in Figure S1, examination of the sized ash showed an enrichment of $\mathrm{Fe}$ in the coarser fly ash particles. This can also be observed based on the variations of $\mathrm{Fe}$ content in the raw fly samples from different baghouse hoppers. From the first-row fly ash to the third-row fly ash, the contents of Fe decreased along with the decreasing ash particle sizes (Table 1). Therefore, most of the Fe oxides are probably present as individual coarse particles, as indicated by the mesh sizes of the fly ash. Interestingly, the variations of arsenic also display an enrichment in the coarse fly ash particles (Figure S1). Further, the surface analysis by XPS reveals that both arsenic and selenium peak in the coarsest fly ash fractions (93259 60-mesh ash). This is not anticipated as many previous studies reported the preferential condensation or absorption of volatile species onto the smaller particles during the post-combustion process. ${ }^{2,5,36}$ Obviously, combined with the data from XPS and XAES experiments, the large amounts of Fe oxides play an important role in the significant retention of As and Se in the stoker fly ash surface.

The partitioning of arsenic and selenium between the vapor and solids is largely associated with the interactions of gaseous species with ash particles in the post-combustion zone. During high-temperature coal combustion in the stoker boiler, arsenic and selenium in feed coal would mostly vaporize into gas phases, such as $\mathrm{Se}^{0}(\mathrm{~g}), \mathrm{SeO}(\mathrm{g}), \mathrm{SeO}_{2}(\mathrm{~g}), \mathrm{As}_{2} \mathrm{O}_{3}(\mathrm{~g}), \mathrm{AsCl}_{3}$ $(\mathrm{g})$, and $\mathrm{As}_{2} \mathrm{O}_{5}(\mathrm{~g}) .{ }^{17}$ These metalloid vapor phases may be physically and/or chemically absorbed by the iron oxides. Seams and $\mathrm{Wendt}^{37}$ found that a strong correlation relationship existed between the concentration of $\mathrm{As} / \mathrm{Se}$ and $\mathrm{Fe} / \mathrm{Ca}$ content in the size-segregated ash particles collected from a 17 $\mathrm{kW}$ laboratory combustor. They suggested that $\mathrm{Fe}$ and/or Ca provided active sites for surface reactions where Se reacted preferentially with $\mathrm{Fe}$ over $\mathrm{Ca}$. Compared to other mineral components $\left(\mathrm{CaO}\right.$ and $\left.\mathrm{Al}_{2} \mathrm{O}_{3}\right), \mathrm{Fe}$ (III) oxides were found to have the best absorption capability to react with gaseous $\mathrm{As}_{2} \mathrm{O}_{3}$ (g), forming stable arsenates. ${ }^{38}$ In this study, the distribution of Fe oxides among the sized-fraction fly ash samples reveals that most of the iron oxides having relatively larger particle sizes are collected in the first-row baghouse hoppers (Table 1). Consequently, arsenic and selenium that are captured by iron phases have their highest concentrations in the coarsest fly ash surface.

\section{CONCLUSIONS}

The surface chemical characteristics of As-enriched coal fly ash samples were studied by XPS and XAES, especially focusing on the chemical forms of arsenic and selenium in fly ash. Although the concentration of $\mathrm{Se}(200-321 \mu \mathrm{g} / \mathrm{g})$ is significantly lower than that of As $(1378-9379 \mu \mathrm{g} / \mathrm{g})$, Se is found to be more enriched in the fly ash surface with surface ERs being up to 309. Arsenic in the fly ash samples has a binding energy and a kinetic energy in the range of 45.7-46.1 and 1216-1218 eV, respectively. Consequently, the Auger parameter for arsenic is calculated as $1263.3 \pm 0.2 \mathrm{eV}$. The Wagner chemical-state plot derived from the As $3 \mathrm{~d}$ binding energy and As $\mathrm{L}_{3} \mathrm{M}_{45} \mathrm{M}_{45}$ kinetic energy can be effectively used to determine the chemical state of arsenic in fly ash. These results reveal that As is mainly present as $\mathrm{As}(\mathrm{V})$ bonded to oxygen ligands, that is, the $\left[\mathrm{AsO}_{4}\right]^{3-}$ anion in the coal fly ash. The Se $3 \mathrm{~d}$ peak has the main asymmetric peak at $57 \pm 0.7 \mathrm{eV}$ with a broad binding energy range and two chemical forms of Se can be found: elemental Se $(62.0-83.3 \%)$ with a binding energy of Se $3 \mathrm{~d}_{5 / 2}$ at $56.5 \pm 0.2 \mathrm{eV}$ and selenite (16.7-38\%) with a binding energy of $58.5 \pm 0.4 \mathrm{eV}$. On the basis of the XPS data and strong correlations between the concentration of As and Se and the iron content, the extreme enrichment of both arsenic and selenium is probably controlled by iron oxides in the coal fly ash.

\section{ASSOCIATED CONTENT}

\section{S Supporting Information}

The Supporting Information is available free of charge on the ACS Publications website at DOI: 10.1021/acsomega.8b02929.

Chemical analyses of the whole sample and sized fly ash samples and contents of $\mathrm{Fe}$ oxides, As, and $\mathrm{Se}$ as a function of particle size in fly ash 93259 (PDF) 


\section{AUTHOR INFORMATION}

\section{Corresponding Author}

*E-mail: james.hower@uky.edu (J.C.H.).

ORCID

James C. Hower: 0000-0003-4694-2776

Shifeng Dai: 0000-0002-9770-1369

Notes

The authors declare no competing financial interest.

\section{ACKNOWLEDGMENTS}

We thank our reviewers and the editor for their constructive comments.

\section{REFERENCES}

(1) Meij, R. Trace element behavior in coal-fired power plants. Fuel Process. Technol. 1994, 39, 199-217.

(2) Vejahati, F.; Xu, Z.; Gupta, R. Trace elements in coal: Associations with coal and minerals and their behavior during coal utilization - A review. Fuel 2010, 89, 904-911.

(3) Yao, Z. T.; Ji, X. S.; Sarker, P. K.; Tang, J. H.; Ge, L. Q.; Xia, M. S.; et al. A comprehensive review on the applications of coal fly ash. Earth-Sci. Rev. 2015, 141, 105-121.

(4) Izquierdo, M.; Querol, X. Leaching behaviour of elements from coal combustion fly ash: An overview. Int. J. Coal Geol. 2012, 94, 5466.

(5) Fu, B.; Liu, G.; Sun, M.; Hower, J. C.; Mian, M. M.; Wu, D.; et al. Emission and transformation behavior of minerals and hazardous trace elements (HTEs) during coal combustion in a circulating fluidized bed boiler. Environ. Pollut. 2018, 242, 1950.

(6) Liu, Y.-T.; Chen, T.-Y.; Mackebee, W. G.; Ruhl, L.; Vengosh, A.; Hsu-Kim, H. Selenium Speciation in Coal Ash Spilled at the Tennessee Valley Authority Kingston Site. Environ. Sci. Technol. 2013, 47, 14001-14009.

(7) Goodarzi, F.; Huggins, F. E. Speciation of Arsenic in Feed Coals and Their Ash Byproducts from Canadian Power Plants Burning Subbituminous and Bituminous Coals. Energy Fuels 2005, 19, 905-915.

(8) Huggins, F. E.; Senior, C. L.; Chu, P.; Ladwig, K.; Huffman, G. P. Selenium and Arsenic Speciation in Fly Ash from Full-Scale CoalBurning Utility Plants. Environ. Sci. Technol. 2007, 41, 3284-3289.

(9) Shah, P.; Strezov, V.; Prince, K.; Nelson, P. F. Speciation of As, $\mathrm{Cr}, \mathrm{Se}$ and $\mathrm{Hg}$ under coal fired power station conditions. Fuel 2008, 87, 1859-1869.

(10) Deonarine, A.; Kolker, A.; Foster, A. L.; Doughten, M. W.; Holland, J. T.; Bailoo, J. D. Arsenic Speciation in Bituminous Coal Fly Ash and Transformations in Response to Redox Conditions. Environ. Sci. Technol. 2016, 50, 6099-6106.

(11) Wiramanaden, C. I. E.; Liber, K.; Pickering, I. J. Selenium Speciation in Whole Sediment using X-ray Absorption Spectroscopy and Micro X-ray Fluorescence Imaging. Environ. Sci. Technol. 2010, $44,5389-5394$.

(12) Hower, J. C. Petrographic examination of coal-combustion fly ash. Int. J. Coal Geol. 2012, 92, 90-97.

(13) Hower, J. C.; Graham, U. M.; Dozier, A.; Tseng, M. T.; Khatri, R. A. Association of the Sites of Heavy Metals with Nanoscale Carbon in a Kentucky Electrostatic Precipitator Fly Ash. Environ. Sci. Technol. 2008, 42, 8471-8477.

(14) Brami, Y.; Herut, B.; Shemesh, A.; Cohen, H. Surface Chemical Characteristics of Coal Fly Ash Particles after Interaction with Seawater under Natural Deep Sea Conditions. Environ. Sci. Technol. 1999, 33, 276-281.

(15) Ohki, A.; Nakajima, T.; Sakaguchi, Y.; Iwashita, A.; Takanashi, $\mathrm{H}$. Analysis of arsenic and some other elements in coal fly ash by Xray photoelectron spectroscopy. J. Hazard. Mater. 2005, 119, 213217.

(16) Deng, S.; Shu, Y.; Li, S.; Tian, G.; Huang, J.; Zhang, F. Chemical forms of the fluorine, chlorine, oxygen and carbon in coal fly ash and their correlations with mercury retention. J. Hazard. Mater. 2016, 301, 400-406.

(17) Yan, R.; Gauthier, D.; Flamant, G.; Peraudeau, G.; Lu, J.; Zheng, C. Fate of Selenium in Coal Combustion: Volatilization and Speciation in the Flue Gas. Environ. Sci. Technol. 2001, 35, 14061410.

(18) Atzei, D.; Da Pelo, S.; Elsener, B.; Fantauzzi, M.; Frau, F.; Pierfranco, L.; et al. The chemical state of arsenic in minerals of environmental interest-an XPS and an XAES study. Ann Chim 2003, 93, 11.

(19) Wagner, C. D.; Gale, L. H.; Raymond, R. H. Two-dimensional chemical state plots: a standardized data set for use in identifying chemical states by x-ray photoelectron spectroscopy. Anal. Chem. 1979, 51, 466-482.

(20) Frau, F.; Rossi, A.; Ardau, C.; Biddau, R.; Da Pelo, S.; Atzei, D.; et al. Determination of Arsenic Speciation in Complex Environmental Samples by the Combined Use of TEM and XPS. Microchim. Acta 2005, 151, 189-201.

(21) Soma, M.; Tanaka, A.; Seyama, H.; Satake, K. Characterization of arsenic in lake sediments by X-ray photoelectron spectroscopy. Geochim. Cosmochim. Acta 1994, 58, 2743-2745.

(22) Mardon, S. M.; Hower, J. C.; O'Keefe, J. M. K.; Marks, M. N.; Hedges, D. H. Coal combustion by-product quality at two stoker boilers: Coal source vs. fly ash collection system design. Int. J. Coal Geol. 2008, 75, 248-254.

(23) Dai, S.; Xie, P.; Ward, C. R.; Yan, X.; Guo, W.; French, D.; et al. Anomalies of rare metals in Lopingian super-high-organic-sulfur coals from the Yishan Coalfield, Guangxi, China. Ore Geol. Rev. 2017, 88, 235-250.

(24) Li, X.; Dai, S.; Zhang, W.; Li, T.; Zheng, X.; Chen, W. Determination of As and Se in coal and coal combustion products using closed vessel microwave digestion and collision/reaction cell technology (CCT) of inductively coupled plasma mass spectrometry (ICP-MS). Int. J. Coal Geol. 2014, 124, 1-4.

(25) Dai, S.; Song, W.; Zhao, L.; Li, X.; Hower, J. C.; Ward, C. R.; et al. Determination of Boron in Coal Using Closed-Vessel Microwave Digestion and Inductively Coupled Plasma Mass Spectrometry (ICP-MS). Energy Fuels 2014, 28, 4517-4522.

(26) Biesinger, M. C.; Payne, B. P.; Grosvenor, A. P.; Lau, L. W. M.; Gerson, A. R.; Smart, R. S. C. Resolving surface chemical states in XPS analysis of first row transition metals, oxides and hydroxides: $\mathrm{Cr}$, $\mathrm{Mn}, \mathrm{Fe}, \mathrm{Co}$ and Ni. Appl. Surf. Sci. 2011, 257, 2717-2730.

(27) Silva, L.; Martinello, K.; Mardon S, M.; Hower, J.; SerraRodríguez, C. Fullerenes and Metallofullerenes in Coal-Fired Stoker Fly Ash. Coal Combust. Gasification Prod. 2010, 2, 66.

(28) Catalano, J. G.; Huhmann, B. L.; Luo, Y.; Mitnick, E. H.; Slavney, A.; Giammar, D. E. Metal Release and Speciation Changes during Wet Aging of Coal Fly Ashes. Environ. Sci. Technol. 2012, 46, 11804-11812.

(29) Hower, J. C.; Henke, K. R.; Dai, S.; Ward, C. R.; French, D.; Liu, S.; et al. 2 Generation and nature of coal fly ash and bottom ash. In Coal Combustion Products (CCP's); Robl, T., Oberlink, A., Jones, R., Eds.; Woodhead Publishing, 2017; pp 21-65.

(30) Fantauzzi, M.; Atzei, D.; Elsener, B.; Lattanzi, P.; Rossi, A. XPS and XAES analysis of copper, arsenic and sulfur chemical state in enargites. Surf. Interface Anal. 2006, 38, 922-930.

(31) Kim, C. S.; Chi, C.; Miller, S. R.; Rosales, R. A.; Sugihara, E. S.; Akau, J.; et al. (Micro)spectroscopic Analyses of Particle Size Dependence on Arsenic Distribution and Speciation in Mine Wastes. Environ. Sci. Technol. 2013, 47, 8164-8171.

(32) Rivera, N.; Hesterberg, D.; Kaur, N.; Duckworth, O. W. Chemical Speciation of Potentially Toxic Trace Metals in Coal Fly Ash Associated with the Kingston Fly Ash Spill. Energy Fuels 2017, 31, 9652-9659.

(33) Tian, Q.; Guo, B.; Nakama, S.; Sasaki, K. Distributions and Leaching Behaviors of Toxic Elements in Fly Ash. ACS Omega 2018, 3, 13055-13064.

(34) O'Day, P. A. Chemistry and Mineralogy of Arsenic. Elements 2006, 2, 77-83. 
(35) Ratafia-Brown, J. A. Overview of trace element partitioning in flames and furnaces of utility coal-fired boilers. Fuel Process. Technol. 1994, 39, 139-157.

(36) Davison, R. L.; Natusch, D. F. S.; Wallace, J. R.; Evans, C. A. Trace elements in fly ash. Dependence of concentration on particle size. Environ. Sci. Technol. 1974, 8, 1107-1113.

(37) Seames, W. S.; Wendt, J. O. L. Regimes of association of arsenic and selenium during pulverized coal combustion. Proc. Combust. Inst. 2007, 31, 2839-2846.

(38) Zhang, Y.; Wang, C.; Li, W.; Liu, H.; Zhang, Y.; Hack, P.; et al. Removal of Gas-Phase As2O3 by Metal Oxide Adsorbents: Effects of Experimental Conditions and Evaluation of Adsorption Mechanism. Energy Fuels 2015, 29, 6578-6585.

(39) https://srdata.nist.gov/xps/selEnergyType.aspx, accessed December 13, 2018. 